\title{
METHOTREXATE-INDUCED INTESTINAL MUCOSITIS DELAYS GASTRIC EMPTYING AND GASTROINTESTINAL TRANSIT OF LIQUIDS IN AWAKE RATS
}

\author{
Pedro M. G. SOARES, Lorena 0. LOPES, José Maurício S. C. MOTA, \\ José Nelson BELARMINO-FILHO, Ronaldo A. RIBEIRO and Marcellus Henrique L. P. de SOUZA
}

\begin{abstract}
Context - Methotrexate and other anticancer agents can induce intestinal mucositis, which is one of the most common limiting factor that prevent further dose escalation of the methotrexate. Objectives - To evaluate the gastric emptying and gastrointestinal transit of liquids in methotrexate-induced intestinal mucositis. Methods - Wistar rats received methotrexate (2.5 $\mathrm{mg} / \mathrm{kg} /$ day for 3 days, subcutaneously) or saline. After 1, 3 and 7 days, sections of duodenum, jejunum and ileum were removed for assessment of epithelial damage and myeloperoxidase activity (biochemical marker of granulocyte infiltration). Others rats were pre-treated with methotrexate or saline, gavage-fed after 3 or 7 days with a standard test liquid meal, and sacrificed 10, 20 or 30-min later. Gastric and small intestine dye recoveries were measured by spectrophotometry. Results - After 3 days of methotrexate, there was an epithelial intestinal damage in all segments, with myeloperoxidase activity increase in both in duodenum and ileum. Seven days after methotrexate, we observed a complete reversion of this intestinal damage. There was an increase in gastric dye recoveries after 10, 20, and 30-min post-prandial intervals after 3 days, but not after 7 days, of methotrexate. Intestine dye recoveries were decreased in the first and second segments at $10 \mathrm{~min}$, in the third at $20 \mathrm{~min}$, and in the second and third at $30 \mathrm{~min}$, only after 3 days of methotrexate treatment. Conclusion - Methotrexate-induced intestinal mucositis delays gastric emptying and gastrointestinal transit of liquids in awake rats.
\end{abstract}

HEADINGS - Mucositis. Methotrexate. Gastric emptying. Gastrointestinal transit. Rats.

\section{INTRODUCTION}

Methotrexate (MTX), an antimetabolite, is widely used in current clinical practice for the treatment of neoplasias, psoriasis, rheumatoid arthritis and Crohn's diseases. MTX is a folic acid antagonist ${ }^{(6,13)}$, inhibiting dihydrofolate reductase, an essential enzyme of DNA and RNA synthesis. The efficacy of MTX is often limited by severe side effects and toxic sequelae ${ }^{(2)}$, such as bone marrow supression, oral and intestinal mucositis. The gastrointestinal toxicity is one of the most common limiting factor that prevents further dose escalation of MTX $^{(7)}$.

Methotrexate and other anticancer agents can induce intestinal mucositis that is a mucosa inflammation with intestinal damage. Duncan et al. ${ }^{(5)}$ proposed that intestinal mucositis develops through three inter-linked stages of increasing epithelial dysfunction: the initial inflammatory phase, the epithelial degradation phase, and the ulceration/bacterial phase. Subsequently, there is a re-establishment of functional epithelial ${ }^{(16,22)}$. Recently,
Miyazono et al..$^{(14)}$ demonstrated that neutrophil infiltration and oxidative stress were involved in MTX-induced intestinal mucositis.

Cancer chemotherapy-related upper gastrointestinal symptoms have been associated with delayed gastric emptying and may include early satiety, anorexia, nausea and vomiting. This set of symptoms is often considered as cancer-associated dyspepsia syndrome (CADS), but its pathophysiological mechanisms are not established yet ${ }^{(12)}$. The literature shows that other types of dyspepsia, such as functional dyspepsia( ${ }^{(23)}$ and NSAID-induced dyspepsia ${ }^{(20)}$, could be secondary to gastrointestinal dysmotility. In the present study, we evaluated the effect of MTX-induced intestinal mucositis on gastric emptying and gastrointestinal transit of a liquid test meal in awake rats.

\section{METHODS}

\section{Animals}

Male Wistar rats (180-220 g), provided by our Institution's Central Station, were kept in a temperature

Centro de Biomedicina, Faculdade de Medicina, Universidade Federal do Ceará, Fortaleza, CE, Brasil. Grants from CNPq (Brazil) supported this work. Drs. Ribeiro and Souza are recipients of $\mathrm{CNPq}$ support.

Correspondence: Prof. Marcellus Henrique Loiola Ponte de Souza - Rua Cel. Nunes de Melo, 1315 - Rodolfo Teófilo - 60430-270 - Fortaleza-CE, Brasil. E-mail: souzamar@ufc.br. 
controlled room with water ad libitum, and fasted for $24 \mathrm{~h}$ before all experiments. All animal treatments and surgical procedures were performed in accordance with the Brazilian College of Animal Experimentation (COBEA), and were approval by local ethical committee.

\section{Methotrexate-induced intestinal mucositis}

A model for experimental intestinal mucositis in Wistar rats was used as described previously ${ }^{(24)}$. The rats were randomly assigned to four groups of at least six animals, and were treated with MTX $(2.5 \mathrm{mg} / \mathrm{kg} /$ day, s.c.; Mayne Phar, USA) or vehicle (saline) for 3 consecutive days. After 1,3 or 7 days, the rats were sacrificed by cervical dislocation, and intestinal tissue samples were harvested and prepared for histological studies. Other tissue samples of the same region were excised and immediately frozen at $-70^{\circ} \mathrm{C}$ for later measurement of myeloperoxidase (MPO) activity. Blood was taken by heart puncture for determination of total and differential leukocyte count.

\section{Intestinal morphometry and histopathology}

Samples of duodenum, jejunum and ileum segments were harvested from the animals. A 3-cm segment of duodenum immediately proximal to the ligament of Treitz, a $6-\mathrm{cm}$ section of distal ileum adjacent to the ileocecal valve, and a $6-\mathrm{cm}$ segment of jejunum were collected. The specimens were then fixed in $10 \%$ neutral buffered formalin, embedded in paraffin, sectioned $(5 \mu \mathrm{m})$ and stained with hematoxylin and eosin.

Measurements of the villus heights (from the tip of the villus to the villus-crypt junction) and crypt depths (defined as the depth of the invagination between adjacent villi) were performed by light microscopy using a calibrated micrometer (10x). Ten intact and well-oriented villi and crypts were measured and averaged for each sample.

\section{Intestinal MPO activity}

MPO is an enzyme found primarily in the azurophilic granules of the neutrophils and has been extensively used as a biochemical marker of granulocyte infiltration into various tissues, including the gastrointestinal tract. The extent of neutrophil accumulation in the intestinal mucosa was measured by MPO activity assay as previously described ${ }^{(1)}$. Briefly, 50-100 mg of intestinal tissues was homogenized in $1 \mathrm{~mL}$ of hexadecyltrimethylammonium bromide (HTAB) buffer (Sigma) for each $50 \mathrm{mg}$ of tissue. The homogenates were then centrifuged at $4500 \mathrm{rpm}$ for $7 \mathrm{~min}$ at $4^{\circ} \mathrm{C}$. MPO activity in the resuspended pellet was assayed by measuring the change in absorbance at $450 \mathrm{~nm}$ using o-dianisidine dihydrochloride (Sigma) and 1\% hydrogen peroxide. The results were reported as MPO units/mg of tissue. A unit of MPO activity was defined as that converting $1 \mu \mathrm{mol}$ of hydrogen peroxide to water in $1 \mathrm{~min}$ at $22^{\circ} \mathrm{C}$.

\section{Leukocyte count}

Leukocyte counts were performed by standard methods ${ }^{(18)}$. The rats were anesthetized with an ether overdose, and a heart puncture was then performed for the collection of samples. The total number of leukocyte was determined by using samples diluted in Turk's solution counted in a Neubauer chamber. Results were expressed as number of leukocytes per $\mathrm{mL}$ of sample.

\section{Measurement of gastric emptying and gastrointestinal transit}

For gastric emptying and gastrointestinal transit measurements, we used a modification of the technique previously described ${ }^{(17)}$. Firstly, rats were randomly allocated into the two groups: control (saline), MTX $(2.5 \mathrm{mg} / \mathrm{kg} / \mathrm{day}$ s.c.) for 3 consecutive days. After 3 or 7 days, rats were gavagefed $(1.5 \mathrm{~mL})$ with a standard liquid test meal containing a nonabsorbable marker $(0.5 \mathrm{mg} / \mathrm{mL}$ phenol red in $5 \%$ glucose). After 10, 20 or 30 min, rats were killed by cervical dislocation. The stomach and small intestine were exposed by laparotomy, quickly clamped at the pylorus, cardia, and terminal ileum, and then removed. The stomach and small intestine from the gastroduodenal junction to the cecum were carefully stretched along a meter-stick on a plain table top and divided into the following segments: stomach and five consecutive intestinal segments (P1-P5). Each segment was placed in a measuring cylinder and the volume measured by adding $100 \mathrm{~mL}$ of $0.1 \mathrm{NaOH}$. They were cut into small pieces and homogenized for 30 seconds. The suspension was allowed to settle for $20 \mathrm{~min}$ at room temperature and $10 \mathrm{~mL}$ of the supernatant was centrifuged for $10 \mathrm{~min}(2800 \mathrm{rpm})$. Proteins in $5 \mathrm{~mL}$ of homogenate were precipitated with 0.5 $\mathrm{mL}$ of trichloroacetic acid ( $20 \% \mathrm{w} / \mathrm{v}$, Reagen, Rio de Janeiro, RJ, Brazil) and pelleted by centrifugation for $20 \mathrm{~min}(2800$ $\mathrm{rpm}$ ), and $3 \mathrm{~mL}$ from the supernatant were added to $4 \mathrm{~mL}$ of $0.5 \mathrm{~N} \mathrm{NaOH}$. The absorbance of the sample was read at a wavelength of $540 \mathrm{~nm}$ and expressed as optical density (OD). A standard dilution curve was obtained in each experiment relating the concentration of phenol red to the optical density of the solution in $0.1 \mathrm{~N} \mathrm{NaOH}$ solution. The linear correlation coefficient for the standard dilution curve (a) was established and used to determine the concentration (C) of the solution read at $560 \mathrm{~nm}(\mathrm{C}=\mathrm{OD})$ and afterward the amount of phenol red $(\mathrm{m})$ recovered from each segment $(\mathrm{m}=\mathrm{C} \mathrm{x}$ volume). The percent recovery of phenol red in each segment $(\mathrm{x})$ was expressed according to the following formula: recovery in segment $x 5$ (amount of phenol red recovered in the segment/total amount of phenol red recovered from all six segments).

\section{Statistical analysis}

The results are reported as means \pm S.E.M. for each group. Statistical analysis of the results was performed using analysis of variance (ANOVA) followed by Bonferroni's test. The differences between groups were considered significant at $P<0.05$.

\section{RESULTS}

Only after 3 days of MTX-treatment, there was a significant $(P<0.05)$ shortening of the villi (Figure 1A), increase in crypt 
depth (Figure 1B) and decrease in villus/crypt ratio (Figure 1C), in the duodenum, jejunum and ileum. Seven days after MTX-treatment, we observed a complete reversion of this intestinal damage.

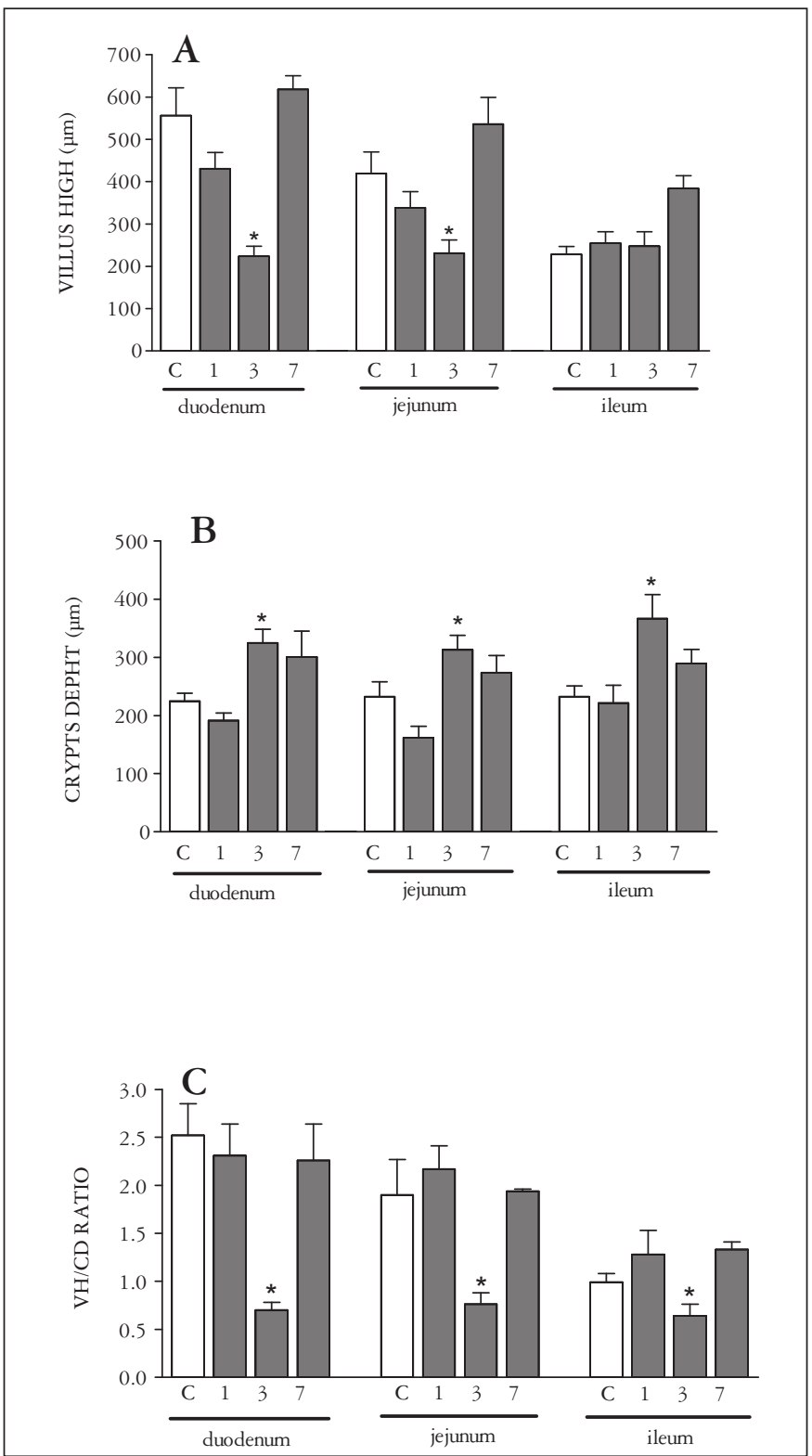

FIGURE 1. Morphometric analyses of VH/CD ratio obtained from experimental ( $\mathbf{\square})$ and normal control $(\mathrm{C}, \square)$ rats (at least six rats for group). Animals were pretreated with $2.5 \mathrm{mg} \cdot \mathrm{kg}^{-1} \mathrm{MTX}$ (1, 3 or 7 days) or vehicle. The values were reported as means $\pm \mathrm{SEM}^{*}, P<0.05$ compared to control after ANOVA and Bonferroni's test

After 1 day of MTX treatment, MPO activity increased in the duodenum and jejunum, but not in the ileum when compared with the control group. In the duodenum and ileum, but not in jejunum, there was an increase in intestinal
MPO activity after 3 days of MTX treatment, which was not observed after 7 days in all segments (Figure 2).
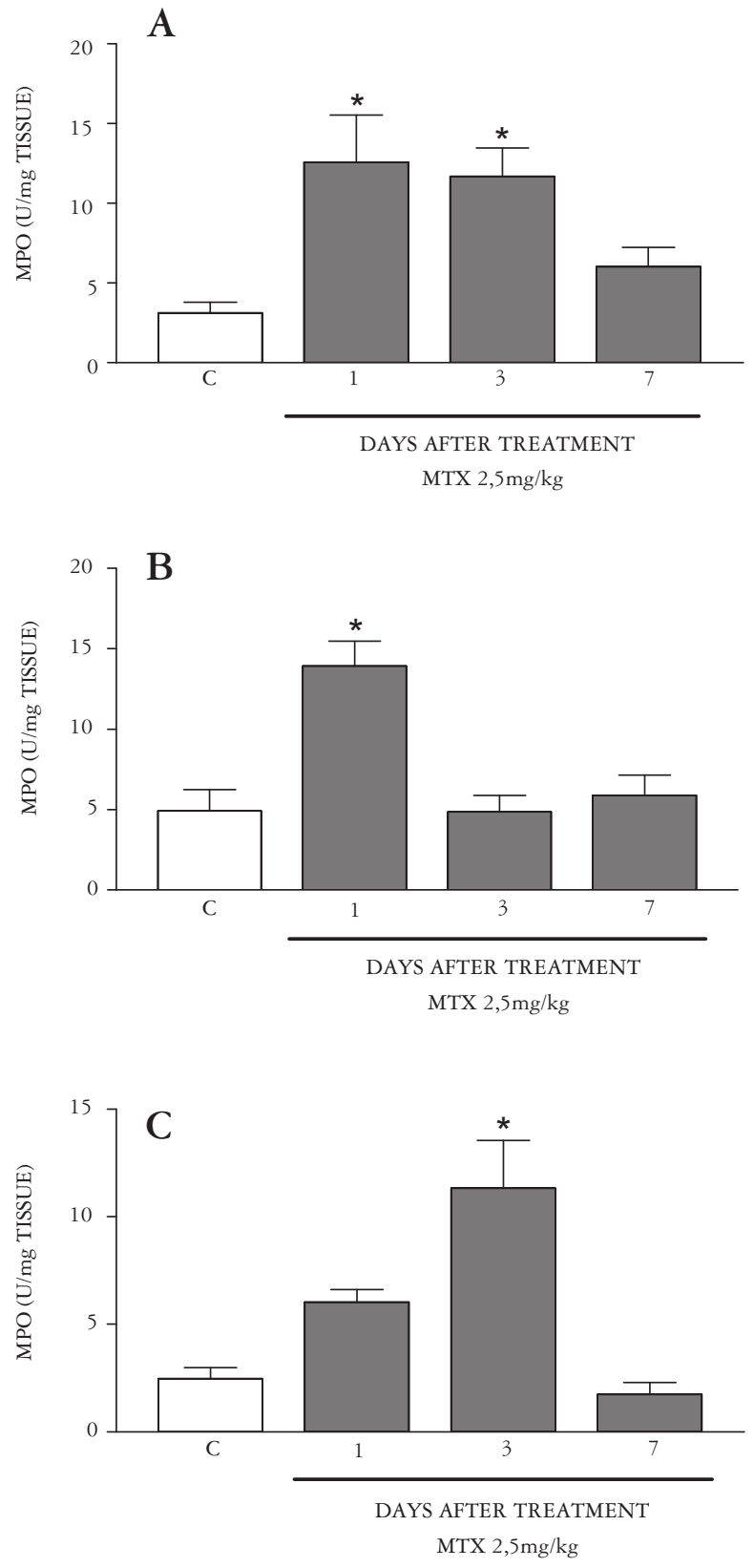

FIGURE 2. Neutrophil infiltration in the duodenum, jejunum and ileum, measured by a myeloperoxidase (MPO) activity assay, from rats treated with $2.5 \mathrm{mg} / \mathrm{kg}$ MTX (1,3, 7 days after treatment) or vehicle (control, C). Animals were killed and samples from the portions of the intestine (duodenum, jejunum and ileum, respectively boxes $\mathrm{A}, \mathrm{B}$ and $\mathrm{C}$ ), were weighed, frozen and stored at $-70^{\circ} \mathrm{C}$ until the MPO activity assay. Results are presented as MPO (U per mg tissue) and reported as means \pm SEM for at least six rats for group*, $P<0.05$ compared to control after ANOVA and Bonferroni's test 
It was observed a significant $(P<0.05)$ leukopenia with MTX treatment at all experimental time points (day $1=4400 \pm 298.3$ cells $/ \mathrm{mL}$, day $3=5938 \pm 1447$ cells $/ \mathrm{mL}$, day $7=5030 \pm 1014$ cells $/$ $\mathrm{mL})$, when compared with control $(9270 \pm 1660$ cells $/ \mathrm{mL})$.

Figure 3 shows that after 3 days, but not after 7 days, of MTX administration, there were an increase $(P<0.05)$ in gastric retention at $10 \mathrm{~min}$ (panel A), $20 \mathrm{~min}$ (panel B) and $30 \mathrm{~min}$ (panel C) post-prandial intervals.

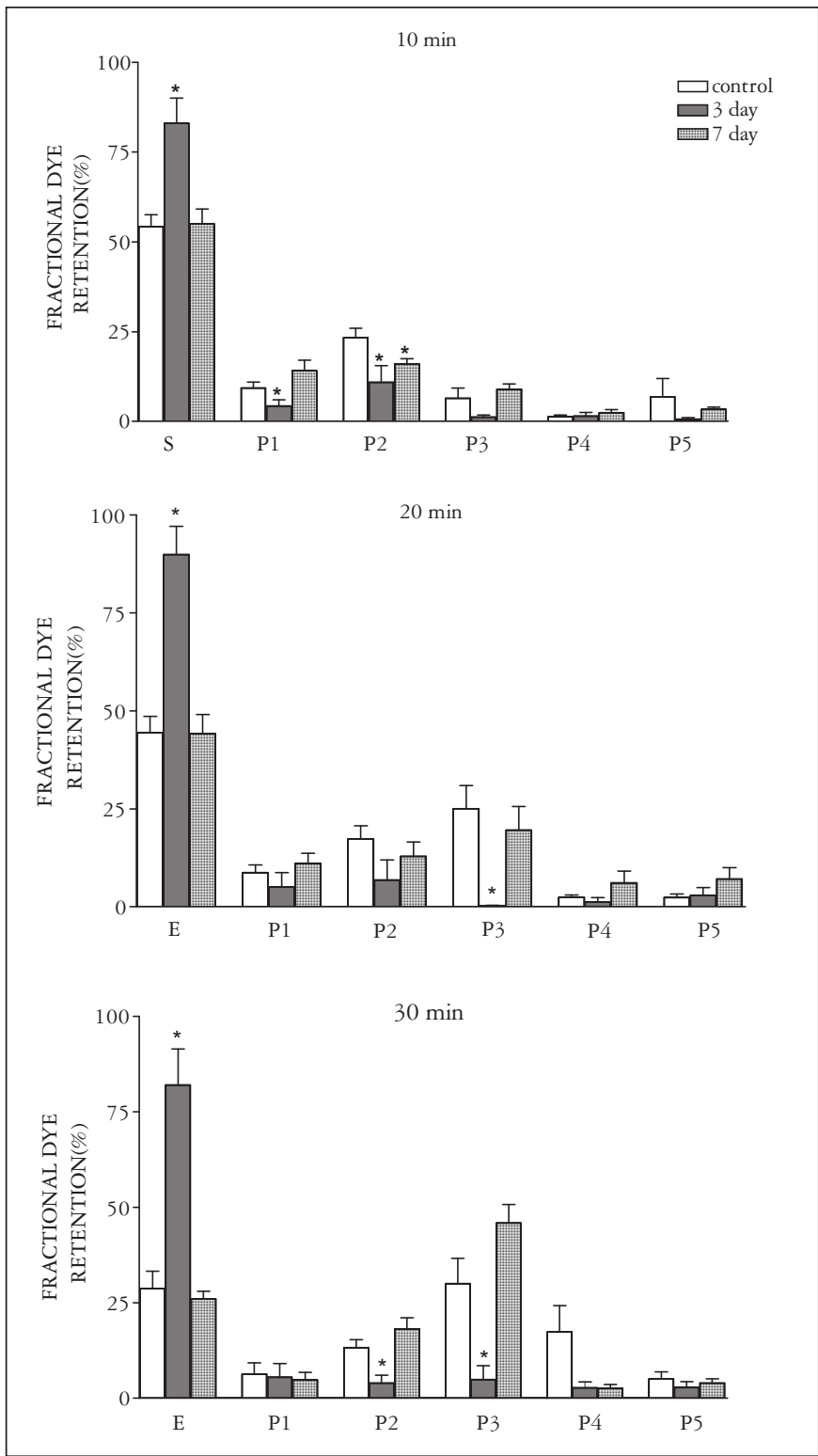

FIGURE 3. Fractional (\%) dye recovery values from stomach (S) and intestine segments (P1-P5), of awake rats studied treated with saline (control- C), and MTX (2.5 mg/kg,) after 3 days or 7 days. Rats were gavage fed with a liquid test meal and sacrificed 10, 20 or 30-min later (respectively boxes A, B and C). The results represent mean values, while vertical bars indicate the standard error of the mean*, $P<0.05$ vs control, after ANOVA and Bonferroni's test
Furthermore, intestinal dye recoveries (IDRs) were significantly decreased $(P<0.05)$ in first and second segments at $10-\min$ (panel A), in the third at 20-min (panel B), and in the second and third at 30-min post-prandial interval (panel $\mathrm{C}$ ), when compared with the control group after 3 days of MTX treatment (panel B). In the panel A, we can see that there was a significant decreased in the IDR at the second segment after 7 days of MTX-treatment.

\section{DISCUSSION}

Gastrointestinal symptoms are the most frequent side effects of antineoplasic chemotherapy, with nausea and vomiting being the main symptoms. However, after the introduction of serotonin receptor antagonists into clinical practice, a dramatic improvement was observed in the management of acute and/or delayed emesis ${ }^{(6)}$. On the other hand, cancer patients may suffer other gastrointestinal symptoms, quite different from emesis, such as dyspepsia, dysphagia and diarrhea, which are not controlled by antiemetic drugg ${ }^{(19)}$. That cluster of symptoms has been referred to as CADS. Recent research suggests that abnormal gastrointestinal motility may also be a cause of $\mathrm{CADS}^{(15,19)}$. One of the most serious side effects during the MTX treatment is gastrointestinal toxicity. Diarrhea and dyspepsia are common complications observed during MTX treatment. Our study showed that MTX-induced intestinal mucositis also decreased the gastric emptying and gastrointestinal transit of liquids in awake rats.

We demonstrated that intestinal histological damage was mainly observed after a 3-day period of methotrexate treatment, followed by a complete mucosal recovery on the 7 th day. We observed an increase in MPO activity in all intestine segments, which was also followed by a recovery, revealing the possible participation of neutrophil infiltration in MTXinduced intestinal mucositis. These results are in accordance with the literature. Miyazono et al. ${ }^{(14)}$ demostrated that oxidative stress and neutrophil infiltration play an important role in MTX-induced small intestinal damage in rats. Duncan and $\mathrm{Grant}^{(5)}$. proposed that the inflammatory phase of chemotherapy-induced mucositis is initiated by a disruption in DNA synthesis, which impairs metabolism in the rapidly dividing progenitor cells of the epithelia. This can lead to mitotic inhibition, disruption of cell-cell and cell-substratum interactions and slight reduction in epithelial integrity. After those events, there is an increase in pro-inflammatory cytokine levels, and then the neutrophil infiltration.

The delay in both gastric emptying and gastrointestinal transit during MTX-induced intestinal mucositis could be due to an increase in gastric compliance and/or an increase in antro-duodenal resistance ${ }^{(8)}$. To the best of our knowledge, there are no studies available at present on the effect of MTXinduced intestinal mucositis on gastric compliance. One possibility is that MTX induced both gastric and intestinal damage, and then inflammation in the stomach induced a gastric dismotility. However, this is not the case, since there was no increase in MPO activity in the stomach during the MTX treatment (data not shown). Since gastrointestinal transit is 
the end result of gastric emptying and intestinal transit, the delay in gastrointestinal transit observed in MTX-induced intestinal damage could be entirely secondary to delayed gastric emptying. This result was in apparent contraction with Curd et al. ${ }^{(3)}$ who demonstrated, in an intestinal transit model, that 3 days of parenteral therapy with MTX significantly increased rat intestinal transit. But it is not the case, because they measured only the progression of an intraduodenally administered of radioactive chromium through the small intestine. In these experiments, they did not evaluate the effect of MTX treatment in gastric motility ${ }^{(3)}$.

One possibility is that MTX-induced gastrointestinal dismotility was a consequence of the inflammatory process in the intestine, observed during the intestinal mucositis. Since, we observed the delayed in gastric emptying and in gastrointestinal transit only when there was an inflammatory process. Since, in the 7th day of MTX treatment, we did not observe neither the inflammatory process nor the gastrointestinal dismotility.

In the last years, it is more apparent that inflammation changes nervous and mucosal function in the gastrointestinal tract. Acute onset of functional dyspepsia, post infectious gastroparesis, and post infectious irritable bowel syndrome are examples of this relationship ${ }^{(21)}$. In addition, there are several other results from experimental models that clearly show an interaction between inflammation and motility. Intestinal hypomotility and delayed gastric emptying have been shown to be characteristic in a mouse model of postoperative ileus ${ }^{(4)}$. It has also been shown that leukocyte- derived inducible nitric oxide (NO) plays an important role in the generation of intestinal inflammation and inhibits GI motility after manipulation in this ileus model ${ }^{(11)}$. It has also been shown in a rat model of hemorrhagic shock, that inducible NO contributes to the inflammatory changes in the gut wall and participates in cytokines expression that impairs the gut motility ${ }^{(10)}$. These observations clearly suggest that inflammation of the gastrointestinal tract causes significant alteration in gut motor function. In our result, we can not role out the participation of NO and other inflammatory mediators in the delay in gastric emptying and gastrointestinal transit observed during MTX-induced intestinal mucositis in rats.

In summary, our results indicate that MTX-induced intestinal mucositis is associated with a delay in gastric emptying and gastrointestinal transit of liquids in awake rats. These novel data suggest that there could be a pathophysiologically linked pathway between intestinal mucositis and the dyspepsia-like syndrome associated with MTX treatment.

\section{ACKNOWLEDGMENTS}

The authors gratefully acknowledge the technical assistance of Maria Silvandira Freire França. Dr. A. Leyva provided English language editing of the manuscript. This work is part of requirements to obtain a $\mathrm{PhD}$ degree in Pharmacology at School of Medicine, Federal University of Ceará by Dr. P.M.G. Soares.

Soares PMG, Lopes LO, Mota JMSC, Belarmino-Filho JN, Ribeiro RA, Souza MHLP. Mucosite induzida pelo metotrexato retarda o esvaziamento gástrico e o trânsito gastrointestinal de líquidos em ratos acordados. Arq Gastroenterol. 48(1):80-5

RESUMO - Contexto-Metotrexato e outros agentes anticâncer podem induzir uma mucosite intestinal, que é um dos fatores de limitante mais comum que limitam o aumento escalonado da dose do metotrexato.Objetivos - Avaliar o esvaziamento gástrico e o trânsito gastrointestinal de líquidos na mucosite intestinal induzida por metotrexato. Métodos - Ratos Wistar, receberam metotrexato $(2.5 \mathrm{mg} / \mathrm{kg} / \mathrm{dia}$ por 3 dias, subcutâneo) ou salina. Após 1, 3 ou 7 dias, secções do duodeno, jejuno e íleo foram retirados para análise morfométrica e dosagem da atividade de mieloperoxidase (marcador bioquímico da infiltração de neutrófilos). Outros ratos foram pré-tratados com metotrexato ou salina, após 3 ou 7 dias, foram alimentados mediante gavagem com uma refeição teste e sacrificados após 10, 20 e 30 minutos. As retenções fracionais do corante no estômago e em três segmentos do intestino delgado foram determinados por espectrofotometria. Resultados - Após 3 dias do metotrexato, houve lesão do epitélio intestinal em todos os segmentos, com aumento da atividade de mieloperoxidase, no duodeno e íleo. Sete dias após o metotrexato, foi observada completa reversão da lesão intestinal. Observou-se ainda retardo no esvaziamento gástrico após $10 \mathrm{~min}, 20 \mathrm{~min}$ e $30 \mathrm{~min}$, após 3 dias, mas não após 7 dias do tratamento com metotrexato. A retenção fracional dos segmentos do intestino foi reduzida no primeiro e segundo segmentos após 10 min, e no terceiro segmento após 30 min da administração da refeição, somente 3 dias após o tratamento com metotrexato. Conclusões - A mucosite intestinal induzida por metotrexato retarda o esvaziamento gástrico e o trânsito gastrointestinal de líquidos em ratos acordados.

DESCRITORES - Mucosite. Metotrexato. Esvaziamento gástrico. Trânsito gastrointestinal. Ratos. 


\section{REFERENCES}

1. Bradley PP, Christensen RD, Rothstein G. Cellular and extracellular myeloperoxidase in pyogenic inflammation. Blood. 1982;60:618-22.

2. Cetiner M, Sener G, Sehirli AO, Ekșioğlu-Demiralp E, Ercan F, Sirvanci S, Gedik $\mathrm{N}$, Akpulat S, Tecimer T, Yeğen BC. Taurine protects against methotrexate-induced toxicity and inhibits leukocyte death. Toxicol Appl Pharmacol. 2005;209:39-50.

3. Curd CD, Manno JE, Stewart JJ. Effects of methotrexate on intestinal transit in rats. Fundam Appl Toxicol. 1985;5: 991-6.

4. de Jonge WJ, Van den Wijingard RM, The FO, ter Beek ML, Bennink RJ, Tytgat GN, Buijs RM, Reitsma PH, Van Deventer SJ, Boeckxstaens GE. Postoperative ileus is maintained by intestinal immune infiltrates that activate inhibitory neural pathways in mice. Gastroenterology. 2003;125:1137-47.

5. Duncan M, Grant G. Oral and intestinal mucositis - causes and possible treatments Aliment Pharmacol Ther. 2003;18:853-74.

6. Fan CC, Vitols KS, Huennekens FM. Inhibition of dihydrofolate reductase by methotrexate: a new look at an old problem. Adv Enzyme Regul. 1980;18:41-52.

7. Grosflam J, Weinblatt ME. Methotrexate: mechanism of action, pharmacokinetics, clinical indications, and toxicity. Curr Opin Rheumatol. 1991:3:363-8.

8. Haba T, Sarna SK. Regulation of gastroduodenal emptying of solids by gastropyloroduodenal contractions. Am J Physiol. 1993;264:g261-71.

9. Hickok JT, Roscoe JA, Morrow GR, King DK, Atkins JN, Fitch TR. Nausea and emesis remain significant problems of chemotherapy despite prophylaxis with 5-hydroxytryptamine-3 antiemetics: a University of Rochester James P. Wilmot Cancer Center Community Clinical Program Study of 360 cancer patients treated in the community. Cancer. 2003;97:2880-6.

10. Hierholzer C, Kalff JC, Billiar TR, Bauer AJ, Tweardy DJ, Harbrecht BG. Induced nitric oxide promotes intestinal inflammation following hemorrhagic shock. Am J Physiol Gastrointest Liver Physiol. 2004;286:g225-33.

11. Kalff JC, Schraunt WH, Billiar TR, Simmons RL, Bauer AJ. Role of inducible nitric oxide synthase in postoperative intestinal smooth muscle dysfunction in rodents. Gastroenterology. 2000;118:316-27.

12. Kris M, Gralla R, Clark R, Tyson L, Groshen S. Control of chemotherapyinduced diarrhoea with synthetic enkephalin BW942C: a randomised trial with placebo in patients receiving cisplatin. J Clin Oncol. 1988;6:663-8.
13. Minaur NJ, Jefferiss C, Bhalla AK, Beresford JN. Methotrexate in the treatment of rheumatoid arthritis. I. In vitro effects on cells of the osteoblast lineage Rheumatology. 2002;41:735-740.

14. Miyazono Y, Gao F, Horie T. Oxidative stress contributes to methotrexateinduced small intestinal toxicity in rats. Scand J Gastroenterol. 2004;11: 1119-27.

15. Nelson K, Walsh D, Sheehan F. Cancer and chemotherapy-related upper gastrointestinal symptoms: the role of abnormal gastric motor function and its evaluation in cancer patients. Support Care Cancer. 2002;10:455-61.

16. Rang HP, Dale MM, Ritter JM. Pharmacology. 4th ed. Edinburgh: Churchill Livingstone; 1999.

17. Reynell PC, Spray GH. The simultaneous measurement of absorption and transit in the gastro-intestinal tract of the rat. J Physiol 1956;131 452-62.

18. Ribeiro RA, Flores CA, Cunha FQ, Ferreira SH. IL-8 causes in vivo neutrophil migration by a cell-dependent mechanism. Immunology 1991;73:472-7.

19. Riezzo G, Clemente C, Leo S, Russo F. The role of electrogastrography and gastrointestinal hormones in chemotherapy-related dyspeptic symptoms. J Gastroenterol. 2005;40:1107-15.

20. Souza MH, Troncon LE, Cunha FQ, Oliveira RB. Decreased gastric tone and delayed gastric emptying precede neutrophil infiltration and mucosal lesion formation in indomethacin-induced gastric damage in rats. Braz J Med Biol Res. 2003;36:1383-90

21. Spiller RC. Inflammation as a basis for functional GI disorders. Best Pract Res Clin Gastroenterol. 2004:18:641-61.

22. Teresi ME, Crom WR, Chui KE, Mirro J, Evans WE. Methotrexate bioavailability after oral and intramuscular administration in children. Pediatr. 1987;110:788-92.

23. Troncon LE, Bennett RJ, Ahluwalia NK, Thompson DG. Abnormal intragastric distribution of food during gastric emptying in functional dyspepsia patients. Gut. 1994;35:327-32

24. Vanderhoof JA, Park JH, Mohammadpour H, Blackwood D. Effects of dietary lipids on recovery from mucosal injury. Gastroenterolology. 1990;98:1226-31.

Received 19/7/2010. Accepted 14/9/2010 